\title{
Using the book of Daniel for solid preaching during a time of persecution
}

\begin{tabular}{|c|c|}
\hline $\begin{array}{l}\text { Book Title: } \\
\text { Preaching Chr } \\
\text { Daniel: Found } \\
\text { expository se }\end{array}$ & $\begin{array}{l}\text { ist from } \\
\text { ations for } \\
\text { mons }\end{array}$ \\
\hline Book Cover: & \\
\hline $\begin{array}{r}\text { SIDNE } \\
\text { GREIDAR }\end{array}$ & \\
\hline $\begin{array}{r}\text { PREACH } \\
\text { CHRI } \\
\text { FANOM } \\
\text { DANI }\end{array}$ & $\begin{array}{l}\text { ING } \\
\mathrm{ST} \\
\mathrm{EL}\end{array}$ \\
\hline $\begin{array}{l}\text { FOUNDATION } \\
\text { EXPOSITORY }\end{array}$ & $\begin{array}{l}\text { SFOR } \\
\text { RMONS }\end{array}$ \\
\hline $\begin{array}{l}\text { Author: } \\
\text { Sidney Greida }\end{array}$ & \\
\hline $\begin{array}{l}\text { ISBN: } \\
978-0-8028-6\end{array}$ & 787-2 \\
\hline $\begin{array}{l}\text { Publisher: } \\
\text { William B. Ee } \\
\text { Publishing Co } \\
\text { 2012, R319.0 } \\
\text { *Book price at }\end{array}$ & $\begin{array}{l}\text { dmans } \\
\text { npany, } \\
\text { ime of review }\end{array}$ \\
\hline $\begin{array}{l}\text { Review Title: } \\
\text { Using the boc } \\
\text { solid preachir } \\
\text { of persecutio }\end{array}$ & $\begin{array}{l}\text { k of Daniel for } \\
\text { g during a time }\end{array}$ \\
\hline $\begin{array}{l}\text { Reviewer: } \\
\text { Robin Gallahe }\end{array}$ & Branch $^{1,2}$ \\
\hline $\begin{array}{l}\text { Affiliations: } \\
{ }^{1} \text { Biblical Studi } \\
\text { University, M }\end{array}$ & $\begin{array}{l}\text { es, Victory } \\
\text { mphis, USA }\end{array}$ \\
\hline $\begin{array}{l}{ }^{2} \text { Faculty of Th } \\
\text { West Univers }\end{array}$ & $\begin{array}{l}\text { eology, North- } \\
\text { ty, South Africa }\end{array}$ \\
\hline $\begin{array}{l}\text { Email: } \\
\text { rgbranch@vic }\end{array}$ & tory.edu \\
\hline $\begin{array}{l}\text { Postal addre } \\
\text { Victory Unive } \\
\text { North Highlar } \\
\text { Tennessee } 38\end{array}$ & $\begin{array}{l}\text { s: } \\
\text { sity, } 255 \\
\text { d, Memphis, } \\
\text { 111, USA }\end{array}$ \\
\hline $\begin{array}{l}\text { How to cite th } \\
\text { Branch, R.G., } \\
\text { the book of D } \\
\text { preaching dur } \\
\text { persecution', } \\
\text { In Luce Verbi } \\
2 \text { pages. http: } \\
10.4102 / \text { ids.V }\end{array}$ & $\begin{array}{l}\text { is book review: } \\
\text { 2013, 'Using } \\
\text { aniel for solid } \\
\text { ing a time of } \\
n \text { die Skriflig/ } \\
\text { 17(1), Art. \#716, } \\
\text { //dx.doi.org/ } \\
47 i 1.716\end{array}$ \\
\hline Read online: & \\
\hline 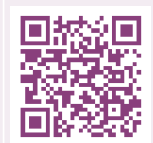 & $\begin{array}{l}\text { Scan this QR } \\
\text { code with your } \\
\text { smart phone or } \\
\text { mobile device } \\
\text { to read online. }\end{array}$ \\
\hline
\end{tabular}

Sidney Greidanus, professor emeritus of preaching at Calvin Theological Seminary, writes a book concentrating on Daniel that is designed to help rectify what he considers the lack of sound preaching from the Old Testament in today's churches. Preaching Christ from Daniel: Foundations for expository sermons opens up the book of Daniel for modern readers and hearers. Whilst geared to preachers for use as a sermon tool, Preaching Christ from Daniel also admirably engages lay readers, for Greidanus writes clearly and logically. For my purposes as an academic, the book will be useful in my upper division Old Testament classes.

Preaching Christ from Daniel covers the entire book of Daniel and thereby serves secondarily as a commentary. Greidanus cites standard sources like Goldingay, Longman, Lucas and Seow, whilst at times disagreeing with them and then explaining his own views. For instance, regarding the identity of the Prince of the Host (Dn 8:11), Greidanus sees the prince as the God of Hosts and not a priest like Onias III or the angel Michael (pp. 260, 267). Similarly, Greidanus does not see the fourth man in the fiery furnace (Dn 3:25) as the preincarnate Christ, but instead as an angel, a type of Christ, who joined the three friends (pp. 95-96).

Greidanus' book follows Daniel's chapters for roughly 12 sermons. Particularly helpful for preachers, I would think, is how he shares his thought processes for each sermon of finding a textual theme and goal (cf. pp. 38, 93, 124, 156, 184, etc.). For instance, in his last chapter with regard to Daniel 12:5-13, he sees its theme as follows: 'God promises everlasting life to his persecuted people who persevere to the end', and the goal of a sermon on this pericope would be 'to encourage God's persecuted people to persevere to the end, for "at the end of the days" God will give them everlasting life' (p. 397).

Greidanus dedicates his book to the Church of Jesus suffering persecution and writes to encourage Christians today 'to remain faithful to the end' (p. v). He notes that the book of Daniel, apocalyptic literature, was written to exilic believers as encouragement that God had not abandoned or forsaken them, despite their present suffering. Sharing modern statistics, he cites estimates that Christian martyrs in the 20th century numbered 45 million, and that since 1990 an average of 160 000 Christians have been martyred every year (p. 82, 82fn.).

Greidanus skilfully joins Daniel's first hearers with his present readers. Regarding Daniel 3:1-30, the story of Daniel's three friends in the fiery furnace, he writes: 'The story of God's ability to save from a fiery furnace gave his exiled people hope: their God is able to deliver them also from the furnace of their exile' (p. 109). He immediately links the Jews' exile to Jesus' ability to 'save us from our exile in this sinful world' (p. 109). The story of the fiery furnace encouraged the Israelites to not bow down to idols, but to remain faithful to their sovereign God, even to death. Likewise, the story encourages us to flee from idolatry, keep the Ten Commandments and remain faithful to God, even unto death (p. 111).

Greidanus' user-friendly and well-edited book provides a plot line graph, but instead of the standard triangle rising to a point for the climax, Greidanus uses a kind of bench. The model contains verse designations from the 'ground' and up a 'leg' to the 'seat' (the plot's climax) and down the other 'leg' until reaching the 'ground' again (see pp. 255, 291, 349, 395, etc.).I found this graph a useful and comprehensive visual aid.

Greidanus frequently advises against quick applications and tiresome moralising. He cites a sermon on Daniel 1 he heard years ago, which advocated that young people should be like Daniel by avoiding rich food, alcohol and sex (p. 30). Such a sermon misses the good news God has for us in that passage, he writes, namely that 'the sovereign Lord, who guided the faithful Daniel and his friends to positions of power in Babylon, will guide his faithful people even in exile' (pp. 30, 39). 
It is obvious that Greidanus is an excellent teacher. $\mathrm{He}$ provides a solid introduction (pp. 1-29) in which he addresses various issues like Daniel's date (around the 6th century BC), the author (probably an editor using Daniel's memoirs), and the history covered by the book (from the Babylonian, MedoPersian, Greek, Egyptian, Syrian and Roman empires on through to the time of the end). Daniel's overall message is God's sovereignty (p. 21). Greidanus discusses literary issues, like the use of Hebrew and Aramaic, genres and textual markers regarding time (Dn 1:1, 2:1, 8:1, 9:1, 10:1, etc.). He talks knowledgeably throughout his book about the concepts of character, scenes and dialogue. Pausing on narrative portions, he notes the significance of verbs and repetitions. He advises against cutting a pericope down into so-called manageable units (p. 31), since he fears the author's theme might be lost.

Preaching Christ from Daniel contains a wide range of application for teaching, preaching and lay enrichment. It links covenant hearers across generations, reminding them of God's constant faithfulness and sovereignty, despite wayward humanity's persistence at sin. God keeps his word: exile punishes sin (Dt 28:36-37). Greidanus' sobering book opens up the book of Daniel for modern use as a tool with a message for those communities and individuals facing persecution. 